\title{
Nutritional state and exercise performance in patients with chronic obstructive lung disease
}

\author{
A M W J SCHOLS, R MOSTERT, P B SOETERS, L H GREVE, E F M WOUTERS \\ From the Asthma Centre Hornerheide, Horn, and the Departments of Pulmonary Diseases and Surgery, State \\ University Limburg, Maastricht, The Netherlands
}

ABSTRACT The relation between exercise performance and certain measures of nutritional state was investigated in 83 patients with stable chronic obstructive lung disease (mean age 62 (8) years). All patients had a forced expiratory volume in one second $\left(F E V_{1}\right)$ less than $50 \%$ predicted, an arterial oxygen tension of more than $7.3 \mathrm{kPa}$, and no severe locomotor, cardiovascular, neurological, or endocrine disorders. Exercise performance was assessed from a 12 minute walking test; body weight (as a percentage of ideal weight), creatinine height index, and serum concentrations of albumin, transferrin, and prealbumin were assessed as measures of nutritional state. Mean values of the nutritional variables were within the normal range. The mean (SD) 12 minute walking distance was 686 (254) metres. Walking distance was positively associated with serum albumin concentration and creatinine height index but not with body weight, serum prealbumin, or serum transferrin concentrations. When patients were categorised into low, medium and high performance groups on the basis of their walking distance, a very low creatinine height index (mean (SD) $59 \%(19 \%)$ ) was found in the low performance group. Albumin explained part of the variance in walking distance independently of pulmonary function in a stepwise regression analysis. The findings suggest that in patients with chronic airflow obstruction skeletal muscle mass and serum albumin concentration are positively associated with exercise performance as measured with a 12 minute walk.

\section{Introduction}

Chronic cough, expectoration, and dyspnoea are common symptoms in patients with chronic obstructive lung disease, many of whom are severely disabled by breathlessness and exercise impairment. Limitation of exercise is related to many factors, including abnormal pulmonary mechanics, impairment of pulmonary gas exchange and ventilatory control, abnormal perception of breathlessness, impaired cardiac performance due to pulmonary hypertension and ventricular failure, poor nutritional state, and the development of respiratory muscle fatigue. ${ }^{\prime}$ Determination of the various factors and their relative importance in an individual patient is difficult and often impossible. The inability to characterise accurately the exercise limiting factors in individual patients has led to confusion and controversy in

Address for reprint requests: Dr A M W J Schols, Department of Pulmonary Diseases, University Hospital Maastricht, PO Box 1918, 6201 BX Maastricht, The Netherlands.

Accepted 13 July 1989 assessing the effectiveness of various forms of treatment designed to improve exercise performance. ${ }^{2}$

Over the past few years several studies have indicated that nutritional state is impaired in a high proportion of patients with chronic obstructive lung disease. $^{3-5}$ Weight loss is common with severe disease. ${ }^{6}$ Malnutrition is a leading cause of impaired respiratory muscle contractility, affecting both strength and endurance.' In patients with severe malnutrition significant changes in respiratory and limb muscle contraction and relaxation characteristics and fatigability properties have been described. ${ }^{89}$ The aim of our study was to evaluate the relation between some measures commonly used for assessing nutritional state and exercise performance in patients with stable chronic obstructive lung disease.

\section{Methods}

The study group consisted of 83 patients with chronic obstructive lung disease with severe airflow obstruction (forced expiratory volume in one second $\left(\mathrm{FEV}_{1}\right)$ less than $50 \%$ of predicted ${ }^{10}$ ) admitted to the pulmonary rehabilitation centre for physical training. 
Patients with cardiovascular, neurological, endocrine, and locomotor diseases and those with an arterial oxygen tension $\left(\mathrm{PaO}_{2}\right)$ below $7 \cdot 3 \mathrm{kPa}^{11}$ were excluded from exercise testing. The patients were in a stable clinical condition. Maintenance medication in all patients included theophylline, beta ${ }_{2}$ agonists, and inhaled or oral corticosteroids.

\section{LUNG FUNCTION}

FEV $_{1}$ and inspiratory vital capacity (IVC) were measured with a wet spirometer, the highest value from at least three spirometric manoeuvres being used. FEV $_{1}$ and IVC were expressed as percentages of the reference values. ${ }^{10}$ Blood was taken from the brachial artery for blood gas analysis. Right ventricular hypertrophy was assessed by electrocardiography in 79 patients by two independent observers.

\section{EXERCISE PERFORMANCE}

Exercise performance was evaluated by a 12 minute walking test, performed in a level, enclosed corridor according to the method described by McGavin. ${ }^{12}$ All tests were performed in the early afternoon and no encouragement was given. As learning effects have been noticed to occur quickly with repeated walking tests, ${ }^{12}{ }^{13}$ the patients performed one practice 12 minute walking test.

\section{NUTRITIONAL STATE}

Height and weight; 24 hour urinary creatinine excretion; and serum albumin, prealbumin, and transferrin concentrations were measured to assess nutritional state. Body weight was compared with a reference value based on height, sex, and frame size from the Metropolitan Life Insurance Company weight standards, ${ }^{14}$ the ratio being expressed as a percentage of ideal weight. A fasting blood sample was drawn for measurement of serum protein concentrations. Serum albumin concentrations were measured by fractionation by standard electrophoresis and serum transferrin and prealbumin concentrations by radial immunodiffusion. Skeletal muscle mass was estimated from the creatinine height index (the 24 hour urinary creatinine excretion divided by a reference value based on percentage of ideal body weight). ${ }^{\text {is }}$ All measurements were done immediately after admission to the centre.

\section{STATISTICAL ANALYSIS}

Descriptive statistics are given as mean (SD). Nutritional measures were correlated with exercise performance by means of the product moment correlation coefficient. As many biochemical variables are affected by age, ${ }^{16}$ partial correlation coefficients were computed, adjusted for a possible confounding age effect. Patients were divided into low, medium, and high exercise performance groups, the medium performance group consisting of patients walking within one SD of the mean walking distance of the total group, and the low and high performance groups being more than one SD below and above the mean walking distance respectively. The three groups were compared for nutritional and lung function measures by one way analysis of variance. After the simple correlations had been completed a linear model was fitted to the data to enable the variables that contributed to the 12 minute walking distance to be determined by stepwise regression analysis.

\section{Results}

The study group consisted of 83 patients, 21 of whom had recently been discharged from hospital. Seven patients were currently receiving antibiotic treatment for a chest infection. The mean age of the 71 men and 12 women was $62(8)$ years. Mean (SD) inspiratory

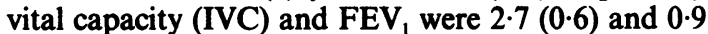
$(0.3) 1$ respectively. Signs of right ventricular hypertrophy were found in 46 patients.

Although mean values of the nutritional variables were within the normal range, a substantial number of patients had a body weight less than $90 \%$ of ideal body weight $(n=21)$ or a creatinine height index less than $60 \%$ or both $(n=35)$. Twenty seven patients reported recent weight loss ( $\geqslant 10 \%$ of previous body weight). None of the nutritional measures correlated significantly with age.

The mean 12 minute walking distance was $686(254)$ metres. The mean difference between the test carried out during the study and the practice test was $+100 \cdot 6$ metres, with a $95 \%$ confidence interval of 72 to 129 metres.

The 12 minute walking distance showed a significant correlation with the serum albumin concentration and creatinine height index but no association with body weight or serum prealbumin or transferrin concentration (table 1). There were no Table 1 Partial correlation coefficients between nutritional measures, lung function, and 12 minute walking distance

\begin{tabular}{lll}
\hline & \multicolumn{2}{l}{12 minute walking distance } \\
\cline { 2 - 3 } & $r$ & $p$ \\
\hline Percentage ideal body weight & 0.19 & $\mathrm{NS}$ \\
Creatinine height index & 0.35 & 0.001 \\
Serum concentrations of: & & \\
albumin & 0.44 & 0.001 \\
transferrin & 0.09 & $\mathrm{NS}$ \\
prealbumin & 0.10 & $\mathrm{NS}$ \\
Inspiratory vital capacity & 0.21 & 0.03 \\
FEV & 0.29 & 0.002 \\
Arterial oxygen tension & 0.42 & 0.001 \\
Arterial carbon dioxide tension & 0.21 & 0.03 \\
\end{tabular}

IVC-inspiratory vital capacity; $\mathrm{FEV}_{1}$ - forced expiratory volume in one second; $\mathrm{PaO}_{2}, \mathrm{PaCO}_{2}$-arterial oxygen and carbon dioxide tension. 
Table 2 Nutritional and lung function variables (mean (SD)) categorised by 12 minute walking distance

\begin{tabular}{|c|c|c|c|c|c|c|c|}
\hline \multirow{2}{*}{$\begin{array}{l}\text { Walking (metres) performance } \\
\text { Percentage ideal body weight } \\
\text { Creatinine height index }(\%) \\
\text { Serum concentrations }(\mathrm{g} / \mathrm{l} \text { ) }\end{array}$} & \multicolumn{2}{|c|}{$<432$, low } & \multicolumn{2}{|c|}{$432-940$, medium } & \multicolumn{2}{|c|}{$>940$, high } & \multirow{2}{*}{$\begin{array}{l}p \\
\text { NS } \\
0.006\end{array}$} \\
\hline & $\begin{array}{l}98 \\
59\end{array}$ & $\begin{array}{l}\text { (12) } \\
\text { (19) }\end{array}$ & $\begin{array}{l}98 \\
98\end{array}$ & $\begin{array}{l}(16) \\
(18)\end{array}$ & $\begin{array}{r}102 \\
86\end{array}$ & $\begin{array}{l}(10) \\
(25)\end{array}$ & \\
\hline $\begin{array}{l}\text { albumin } \\
\text { transferrin } \\
\text { prealbumin } \\
\text { IVC }(\% \text { predicted }) \\
\mathrm{FEV}_{1}(\% \text { predicted }) \\
\mathrm{PaO}_{2}(\mathrm{kPa}) \\
\mathrm{PaCO}_{2}(\mathrm{kPa})\end{array}$ & $\begin{array}{c}37.9 \\
2.5 \\
0.30 \\
62 \\
31 \\
9.0 \\
5.3\end{array}$ & $\begin{array}{l}(4 \cdot 7) \\
(0 \cdot 04) \\
(0 \cdot 05) \\
(16) \\
(9) \\
(0 \cdot 9) \\
(0 \cdot 7)\end{array}$ & $\begin{array}{c}41 \cdot 6 \\
2 \cdot 6 \\
0 \cdot 29 \\
69 \\
31 \\
9 \cdot 7 \\
5 \cdot 2\end{array}$ & $\begin{array}{l}(4 \cdot 3) \\
(0 \cdot 03) \\
(0 \cdot 08) \\
(14) \\
(9) \\
(1 \cdot 4) \\
(0 \cdot 7)\end{array}$ & $\begin{array}{c}44 \cdot 3 \\
2 \cdot 6 \\
0 \cdot 31 \\
74 \\
36 \\
10 \cdot 9 \\
4 \cdot 9\end{array}$ & $\begin{array}{l}(3 \cdot 6) \\
(0.05) \\
(0.07) \\
(16) \\
(7) \\
(2 \cdot 0) \\
(0 \cdot 6)\end{array}$ & $\begin{array}{l}0.001 \\
\text { NS } \\
\text { NS } \\
\text { NS } \\
\text { NS } \\
0.005 \\
\text { NS }\end{array}$ \\
\hline
\end{tabular}

IVC-inspiratory vital capacity; $\mathrm{FEV}_{1}$ - forced expiratory volume in one second; $\mathrm{PaO}_{2}, \mathrm{PaCO}_{2}$ - arterial oxygen and carbon dioxide tension.

significant differences in spirometric measures between the low, medium, and high performance groups (table 2). $\mathrm{PaO}_{2}$ was significantly different between the three groups.

Right ventricular hypertrophy was not associated with impaired exercise performance. Weight loss was reported more often in the low (36\%) and medium $(67 \%)$ performance groups than in the high $(7 \%)$ performance group. The creatinine height index was below normal in the low performance group. Serum albumin concentration was low in the low performance group and lower in the medium than in the high performance group. Albumin was positively associated with $\mathrm{PaO}_{2}(\mathrm{r}=0.28, \mathrm{p}<0.005)$. In the regression analysis (table 3 ) serum albumin explained part of the variance in 12 minute walking distance after inclusion of spirometric measures and arterial blood gas tensions in the model.

\section{Discussion}

Many patients with chronic obstructive lung disease suffer from severe exercise impairment. The 12 minute walking test has been proposed as a simple and reproducible test to assess exercise performance in these patients. ${ }^{12}$ Several studies have related exercise performance to spirometric measures. Small but significant correlations were found between walking distance and IVC and FEV, by some authors ${ }^{17-20}$ but not by others. ${ }^{1321}$

In this study we assessed whether impairment of exercise performance is associated with an impaired nutritional state. Only patients with an $\mathrm{FEV}_{1}$ less than $50 \%$ of the predicted value were included, to increase the homogeneity of the study group. We established an association between 12 minute walking distance, creatinine height index, and serum albumin concentration.

In patients with chronic obstructive lung disease body weight as a percentage of ideal body weight is commonly used as an indicator of nutritional state. In our study, however, in agreement with the results of other authors using the six minute walking distance, ${ }^{22} 23$ body weight expressed as a percentage of ideal body weight was not correlated with walking distance.

In patients with severe chronic obstructive lung disease muscle mass cannot be assumed to increase simultaneously with increasing body weight. Variability in body fat and extracellular fluid volume between patients may be quite large as a result of immobility and fluid retention. In addition to body weight we therefore assessed the creatinine height index. ${ }^{24} 25$ Creatine and phosphocreatinine in muscle are non-enzymatically dehydrated to form creatinine, which is excreted in the urine. If the proportion of phosphocreatinine and creatine in muscle is constant, the production and excretion of creatinine in the urine over 24 hours provides a measure of muscle mass. ${ }^{26}$ Creatinine excretion in healthy individuals correlates well with oxygen use and lean body mass. ${ }^{24}$ In patients with wasting disease, however, the creatinine height

Table 3 Determinants of variation in 12 minute walking distance

\begin{tabular}{|c|c|c|c|c|c|}
\hline Variable & $R^{2}$ model + & $F$ model $\$$ & $D f$ & $F$ variable & $D f$ \\
\hline $\begin{array}{l}\text { Albumin } \\
\mathrm{PaO}_{2} \\
\mathrm{Age}^{2}\end{array}$ & $\begin{array}{l}17 \\
28 \\
33\end{array}$ & $\begin{array}{l}16 \cdot 9^{* * *} \\
15 \cdot 4^{* * *} \\
13 \cdot 1^{* * *}\end{array}$ & $\begin{array}{l}1.82 \\
2.81 \\
3.80\end{array}$ & $\begin{array}{c}13 \cdot 0^{* * *} \\
10 \cdot 1^{* * *} \\
6 \cdot 4^{*}\end{array}$ & $\begin{array}{l}1.79 \\
1.79 \\
1.79\end{array}$ \\
\hline
\end{tabular}

$\mathrm{p}=0.01 ; * * \mathrm{p}=0.001$.

$+R^{2}=100^{*}$ (regression sum of squares)/(total sum of squares) for model consisting of current and preceding variables.

$\ddagger$ Model consisting of current and preceding variables.

$\S$ After adjustment for the remaining variables.

$\mathrm{PaO}_{2}-$ arterial oxygen tension. 
index falls, and is no longer related to body weight. These changes presumably result from a distortion of body composition, especially the loss of protein. ${ }^{27}$ It has been shown that fluid retention does not alter an abnormally low creatinine height index even when body weight is affected. ${ }^{28}$ A $20 \%$ decrease in the creatinine height index between the ages of 65 and 74 years is considered to be a normal decline with advancing age. A value of less than $60 \%$, however, is considered to indicate a severe deficit of muscle mass. ${ }^{24}$ Further data, including serial values for the creatinine height index, need to be obtained to determine whether loss of muscle mass, as may happen with weight loss, is related to change in exercise performance.

Albumin, prealbumin, and transferrin concentrations are commonly used measures of visceral protein. ${ }^{15}$ Prealbumin is more sensitive to short term nutritional depletion and repletion than albumin, because it has a very short half life; but there was no association between 12 minute walking distance and serum prealbumin concentration. This might be due to a large between day variability of prealbumin or sensitivity of the measurement to metabolic stress, such as bronchial infection or to chronic corticosteroid medication, ${ }^{29}$ or to a combination of these. The low correlation coefficient between the 12 minute walking distance and serum transferrin concentrations could, in part at least, be explained by the fact that serum iron concentration in patients with chronic obstructive lung disease does not reflect iron stores as much as the adjustment of the body to hypoxaemia. ${ }^{3}$

Of three possible causes of the decrease in serum albumin, an excessive shift in body fluids is unlikely in the group under study, because of the inclusion criteria we used: all patients were in a stable cardiac and pulmonary condition. Serum albumin concentrations were also not different in the patients with right ventricular hypertrophy. The relative effects of malnutrition and the overall stress of the chronic disease process on serum albumin concentrations cannot yet be established. Albumin was not related to body weight expressed as a percentage of ideal body weight but was positively associated with arterial oxygen tension. In keeping with the findings of an earlier study, the results suggest that low serum albumin concentrations in patients with chronic obstructive lung disease may be due to chronic hypoxaemia. ${ }^{30}$

\section{References}

1 Loke J, Mahler D, Man SFP, Wiedemann HP, Matthay RA. Exercise impairment in chronic obstructive pulmonary disease. Clin Chest Med 1984;5:121-43.

2 Medical section of the American lung association. Standards for the diagnosis and care of patients with chronic obstructive pulmonary disease (COPD) and asthma. Am Rev Respir Dis 1987;135:239-43.

3 Hunter AMB, Carey MA, Larsh HW. The nutritional status of patients with chronic obstructive pulmonary disease. Am Rev Respir Dis 1981;124:376-81.

4 Openbrier DR, Irwin MM, Rogers MM, et al. Nutritional status and lung function in patients with emphysema and chronic bronchitis. Chest 1983;83: 17-22.

5 Driver AG, McAlevy MT, Smith JL. Nutritional assessment of patients with chronic obstructive pulmonary disease and acute respiratory failure. Chest 1982; 82:568-71.

6 Vandenbergh E, Woestijne van de KP, Gyselen A. Weight changes in the terminal stages of chronic obstructive pulmonary disease. Relation to respiratory function and prognosis. Am Rev Respir Dis 1967; 95:556-66.

7 Arora NS, Rochester DF. Respiratory muscle strength and maximal voluntary ventilation in undernourished patients. Am Rev Respir Dis 1982;126:5-8.

8 Lopes J, Russell DMcR, Whitwell J, Jeejeebhoy KN. Skeletal muscle function in malnutrition. Am J Clin Nutr 1982;36:602-10.

9 Russell DMcR, Prendergast PJ, Darby PL. A comparison between muscle function and body composition in anorexia nervosa: the effect of refeeding. Am J Clin Nutr 1983;38:229-37.

10 Quanjer $\mathrm{Ph}$, ed. Standardized lung function testing. Bull Eur Physiopathol Respir 1983;19(suppl 5):7-44.

11 Belman MJ. Exercise in chronic obstructive pulmonary disease. Clinics Chest Med 1986;7:585-97.

12 McGavin CR, Gupta SP, McHardy GJR. Twelve minute walking tests for assessing disability in chronic bronchitis. Br Med J 1976;1:822-3.

13 Beaumont A, Cockroft A, Guz A. A self paced treadmill walking test for breathless patients. Thorax 1985; 40:459-64.

14 Metropolitan Life Insurance Company. New weight standards for men and women. New York Metropolitan Life Insurance Company statistical bulletin 1959;40:1-4.

15 Jensen TG, Engbert DM, Dudrick SJ. Nutritional assessment. A manual for practitioners. Norwalk, Connecticut: Appleton-Century-Crofts, 1983.

16 Mitchell CD, Lipschitz DA. Detection of protein-calorie malnutrition in the elderly. Am J Clin Nutr 1982;35:398-406.

17 Dekhuizen PNR, Kaptein AA, Dekker FW, Wagenaar JPM, Janssen PJ. Twelve minute walking test in a group of Dutch patients with chronic obstructive pulmonary diseases; relationship with functional capacity. Eur J Respir Dis 1986;69:259-64.

18 McGavin CR, Artvinly M, Naoe H, McHardy GJR. Dyspnoea, disability, and distance walked: comparison of estimates of exercise performance in respiratory disease. Br Med J 1978;ii:241-3.

19 Morgan AD, Peck DF, Buchanan DR, McHardy GJR. Effects of attitudes and beliefs on exercise tolerance in chronic bronchitis. $\mathrm{Br} \mathrm{Med} J$ 1983;286:171-3.

20 Light RW, Merrill EJ, Despars JA, Gordon GH, Multalipassi WR. Prevalence of depression and anxiety in patients with COPD; relationship to functional capacity. Chest 1985;87:35-8. 
21 Mungall IPF, Hainsworth R. Assessment of respiratory function in patients with chronic obstructive pulmonary airway disease. Thorax 1979;34:254-8.

22 Efthimiou J, Fleming J, Gomes C, Spiro SG. The effect of supplementary oral nutrition in poorly nourished patients with chronic obstructive pulmonary disease. Am Rev Respir Dis 1988;137:1075-82.

23 Gray-Donald K, Carrey Z, Martin JG. Effect of nutritional status on exercise performance in COPD. Am Rev Respir Dis 1988;137:154.

24 Forbes GB, Bruining GJ. Urinary creatinine excretion and lean body mass. Am J Clin Nutr 1976;29:1359-66.

25 Heymsfield SB, Arteaga C, McManus C, Smith J, Moffit S. Measurement of muscle mass in humans: validity of the urinary creatinine method. Am J Clin Nutr 1983;37:478-94.

26 Webster J, Garrow JS. Creatinine excretion over 24 hours as a measure of body composition or of completeness of urine collection. Human Nutrition, Clinical Nutrition 1985;39C:101-6.

27 Blackburn GL, Thornton PA. Nutritional assessment of the hospitalized patient. Med Clin North Am 1979; 5:1103-15.

28 Bistrian BR, Blackburn GL, Sherman M. Therapeutic index of nutritional depletion in hospitalized patients. Surg Gynec Obstet 1975;141:512-6.

29 Morton RE, Hutchings J, Halliday D, Rennie MJ, Wolman SL. Protein metabolism during treatment of chest infection in patients with cystic fibrosis. Am J Clin Nutr 1988;47:214-9.

30 Schols AMWJ, Mostert R, Soeters PB, Greve LH, Wouters EFM. Inventory of nutritional status in chronic obstructive pulmonary disease. Chest 1989; 95:247-50. 